\title{
Modelling of A Solar Thermal Energy System For Energy Efficiency Improvement In A Ceramic Plant
}

\author{
Miguel Castro Oliveira* (D) and Muriel Iten (D) \\ Low Carbon \& Resource Efficiency, R\&D, Instituto de Soldadura e Qualidade, Portugal
}

Received: 3 July 2021 / Received in final form: 16 August 2021 / Accepted: 17 August 2021

\begin{abstract}
The thermal energy use in the manufacturing plants is the most representative parcel of the total energy consumption within the European industry. Such is mainly attributed to the operation of high energy intensive thermal processes such as furnaces and boilers. The implementation of heat recovery technologies is a solution with a great potential to improve the operation of these processes and improve the overall energy efficiency in a plant. On the other hand, the use of renewable energy resources such as solar energy is highly relevant measure to decrease the use of fossil fuels, such as natural gas. This paper presents the modelling of a solar thermal energy system (STES) established by a water circuit and solar thermal collector for the heat supply to two boilers installed in a ceramic plant. Such system has been conceptualised in the scope of industrial practices, proposing solar heat for industrial processes (SHIP). The practical work in this paper aims to the development of a customised simulation tool for the modelling of heat recovery networks and thermal processes in manufacturing industry plants using the Modelica language. The system model has been developed using existing and newly developed equipment models. The simulation results were validated with measured data in the industrial plant, being consistent with the real values (e.g. highest deviation of about $0.01 \%$ ). In addition to the boilers, the performed simulation allowed to achieve the sizing of the components of the water circuit, in particular for the pumping system (with a required supply of $0.747 \mathrm{~kW}$ of electric energy). A techno-economic assessment has been performed to evaluate the viability of the cproposed solution, showing a payback time of approximately 3 years, a total annual economic savings of about $25209 €$ and associated reduction of equivalent carbon dioxide emissions of about 170 ton/year.
\end{abstract}

\section{Introduction}

The industrial sector is responsible for about $25 \%$ of the final energy consumption in Europe [1]. Within European industry, such high energy consumption level is mainly due to thermal energy use, accounting for $70 \%$ of the total energy use [2]. Thermal energy is primarily generated by the burning of a fuel (such as natural gas) within the operation of a combustion system [3]. The implementation of energy efficiency improvement relies on the application of several measures [4]. One specific set of measures are the one related to heat recovery, this is, the supply of a determinate quantity of heat to enable savings in the primary heat source (fuel) [5]. Another solution is the use of renewable energy resources (such as solar energy) and the implementation of renewable energy systems, which

\footnotetext{
* e-mail: dmoliveira@isq.pt; mciten@isq.pt
}

simultaneously reduces the consumption of fossil fuels and indirectly improves the plant's overall energy efficiency [6].

The improvement of energy efficiency and the promotion of renewable energy resource use in the European Union has been secured through several policies. In specific, the 2020 climate \& energy package objectives were updated on the most recent 2030 climate \& energy package, in which the minimum targets of $32.5 \%$ improvement in energy efficiency, $32 \%$ share for renewable energy and $40 \%$ cuts in greenhouse gas emissions are established [7].

The research on energy efficiency improvement in the industrial sector subsist on several rigorous methods [8]. A specific method based on the simultaneous application of the principles of heat recovery and renewable energy integration is designated as solar heat for industrial processes (SHIP) [9]. The integration of solar thermal systems is an opportunity with a significant potential at both an economic and environmental level [10,11]. The virtual application of the aforementioned methods subsists 
Table 1. Technical specifications of the plant and the two boilers.

\begin{tabular}{llll}
\hline & \multicolumn{2}{c}{ Plant } \\
\hline Natural gas Consumption $(\mathrm{GWh} /$ year $)$ & 84.47 \\
Operational Time (h/year) & 7824 \\
Boiler 1 & Boiler 2 \\
\hline Natural gas Consumption $(\mathrm{MWh} /$ year $)$ & 137.50 & Natural gas Consumption $(\mathrm{MWh} /$ year $)$ & 137.50 \\
Water Inlet Temperature $\left({ }^{\circ} \mathrm{C}\right)$ & 20 & Water Inlet Temperature $\left({ }^{\circ} \mathrm{C}\right)$ & 20 \\
Water Outlet Temperature $\left({ }^{\circ} \mathrm{C}\right)$ & 95 & Water Outlet Temperature $\left({ }^{\circ} \mathrm{C}\right)$ & 95 \\
Water Flow rate $(\mathrm{kg} / \mathrm{h})$ & 1277.38 & Water Flow rate $(\mathrm{kg} / \mathrm{h})$ & 1180.32 \\
\hline
\end{tabular}

on the development of process and system-level models [12]. Numerical modelling may be applied in a multiscale perspective in order to either develop models for single unit operations in a plant or a building or the whole system which encompasses a set of processes. The Modelica language has been used to develop models and study the implementation of several types of measures [12-15]. Several open source libraries have been developed in Modelica for the simulation of several systems. For instance, the modelling of the overall industrial systems encompassing thermal processes and water networks has been secured by the use of the ThermoPower library [16], with its derivative WaterWatt library being specifically used for the modelling of industrial water circuits $[12,17]$. On the other hand, the Soltermica [18] and SolarTherm [19] have been used to model and simulate several solar thermal systems $[20,21]$. Currently, a customised modelling tool is being developed using the Modelica language aiming to simulate several measures for the rationalization of thermal energy and the valorisation of waste heat streams in manufacturing industry plants. Following the Modelica simulation tool for the planning and assessment of heat recovery networks for several thermal processes [15], the integration of solar thermal systems as additional heat sources, is considered. Such fulfils an existing research gap on planning of such systems on the context of individual plants, as well as the economic and environmental assessment of solar heat for industrial processes.

This paper presents an innovative approach to improve the energy efficiency of a ceramic plant based on a system which combines heat recovery and the use of solar thermal energy. Such approach is studied through the development of a model using the Modelica language. In a broader perspective, this study is inserted in a research study which encompasses energy efficiency in industry (focusing on the optimisation of thermal processes) by performing development modelling and simulation tool. This paper aims to present the modelling approach (equipment and plantlevel), its validation e and evaluate its economic and enviornment potential.

\section{Materials and methods}

In this section, it will be presented the description of the case-study inserted in a ceramic industry plant, the aspects regarding the modelling of the plant's components and the conceptualization of the solar thermal energy system (STES).

\subsection{Description of the case-study}

This case-study is introduced in a ceramic brick manufacturing plant located in Portugal. The production line is constituted by two tunnel kilns, one intermittent kilns, two continuous dryers and four hot water boilers. The plant is located in a zone with high levels of solar irradiation over a year.

Currently, there are already implemented a waste heat recovery strategy in the plant which encompasses the use of the waste heat of the exhaust gas streams of the two kilns to be supplied to brick yards. Nonetheless, currently there is a requirement to optimise the performance of the thermal processes within the plant by reducing the natural gas consumption. Another project (which is also being conceptualized at the same time as the project which is the subject of this paper) encompasses the use of the waste heat potential of these exhaust gases to be used to heat up the water streams at the inlet of two of the boilers, as well as the recycling of hot air from the cooling zone of one tunnel kiln to be used as preheated combustion air in the firing zone of the same kiln. The present study approaches the optimisation of the remaining two boilers. The technical specifications of these boilers are presented in Table 1 (for convenience reasons, these boilers are numbered as boiler 1 and 2).

In this prospect, a new strategy must be defined in order to attend for the described requirement. This study approaches a heat recovery strategy which makes use of solar energy, namely through the installation of solar thermal collectors. The solar thermal energy corresponds to the additional heat source for the operation of the boilers.

\subsection{Modelling of system components}

The proposed WHR strategy will be studied and assessed by assembling a component-based model by interconnecting the operations of the industrial plant. The Modelica language is used for the modelling of the equipment and simulation of the overall operation of the plant. Although 
Table 2. Description of Modelica libraries used to assemble the STES model.

\begin{tabular}{|c|c|c|}
\hline Library & Description & Components \\
\hline ThermoPower [16] & $\begin{array}{l}\text { - A Modelica library developed for the dynamic } \\
\text { simulation of thermal power plants and energy } \\
\text { conversion systems; } \\
\text { - Does not contain models for high-level combustion } \\
\text { processes, but contains several basic models which } \\
\text { may be used for the assembling of such models } \\
\text { (such as combustion chambers, gas flow models and } \\
\text { water flow models). }\end{array}$ & \\
\hline WaterWatt [17] & $\begin{array}{l}\text { - A Modelica libraries developed for the modelling } \\
\text { and simulation of industrial water circuits; } \\
\text { - A considerable part of the component models are } \\
\text { adapted from the component models of } \\
\text { ThermoPower; } \\
\text { - The theoretical assumptions taken in this work in } \\
\text { respect to the component models constituent of the } \\
\text { water circuit encompassed in the STES are the ones } \\
\text { described by Oliveira and Iten [12]; } \\
\text { - The hydraulic phenomena associated to pipe, } \\
\text { tank and pump models is described by } \\
\text { equations (1) - (3), respectively. }\end{array}$ & $\begin{array}{l}\text { - Pipes } \\
\text { - Tank } \\
\text { - Pump (modified version) } \\
\text { - Basic components for the development } \\
\text { of the tunnel kiln and boiler models }\end{array}$ \\
\hline Soltermica [18] & $\begin{array}{l}\text { - A Modelica library developed for the simulation of } \\
\text { low temperature solar thermal systems, focusing on } \\
\text { the design of solar water heating systems; } \\
\text { - Its focus is on residential buildings. }\end{array}$ & - Solar collector (modified version) \\
\hline
\end{tabular}

Table 3. Description of newly developed components.

\begin{tabular}{ll}
\hline Name & Description \\
\hline Solar thermal collector & - It consists in a simplified model for a solar thermal collector; \\
& - The component model was adapted from the solar collector model of \\
& Soltermica; \\
- Two connectors from ThermoPower library for, respectively, the inlet and & outlet of the water stream were added to this model so to make possible the \\
& model to be connected to the components assembled using this library. \\
& - It consists in a hot water boiler; \\
- It is assembled according to the mass and enthalpy balances in a industrial & boiler (water stream and combustion chamber), as described in \\
Boiler & equations (1) - (3); \\
& The thermal efficiency (ratio between supplied energy and the variation of the \\
& enthalpy of the water stream) is considered in the overall mass-enthalpy \\
& balance (thus accounting for the overall heat losses). \\
\hline
\end{tabular}

a part of the component models are included in existing Modelica libraries (which highly reduces the requirements for model development), some models still do not exist in the available libraries. As such, some component models had to be assembled to achieve the aims of this research. Two open source Modelica libraries have been identified for this prospect: ThermoPower [12] and Soltermica [14]. Table 2 presents a general description of each library and the component models which these libraries provide in the scope of this research. Table 3 presents a brief description of the component models developed for the aim of this research: the solar collector (modified version of the one from Soltermica) and the boiler.

$$
\begin{gathered}
p_{\text {out }}-p_{\text {in }}+\Delta p=0 \\
p_{\text {final }}=p_{0}+\rho g y_{T}
\end{gathered}
$$




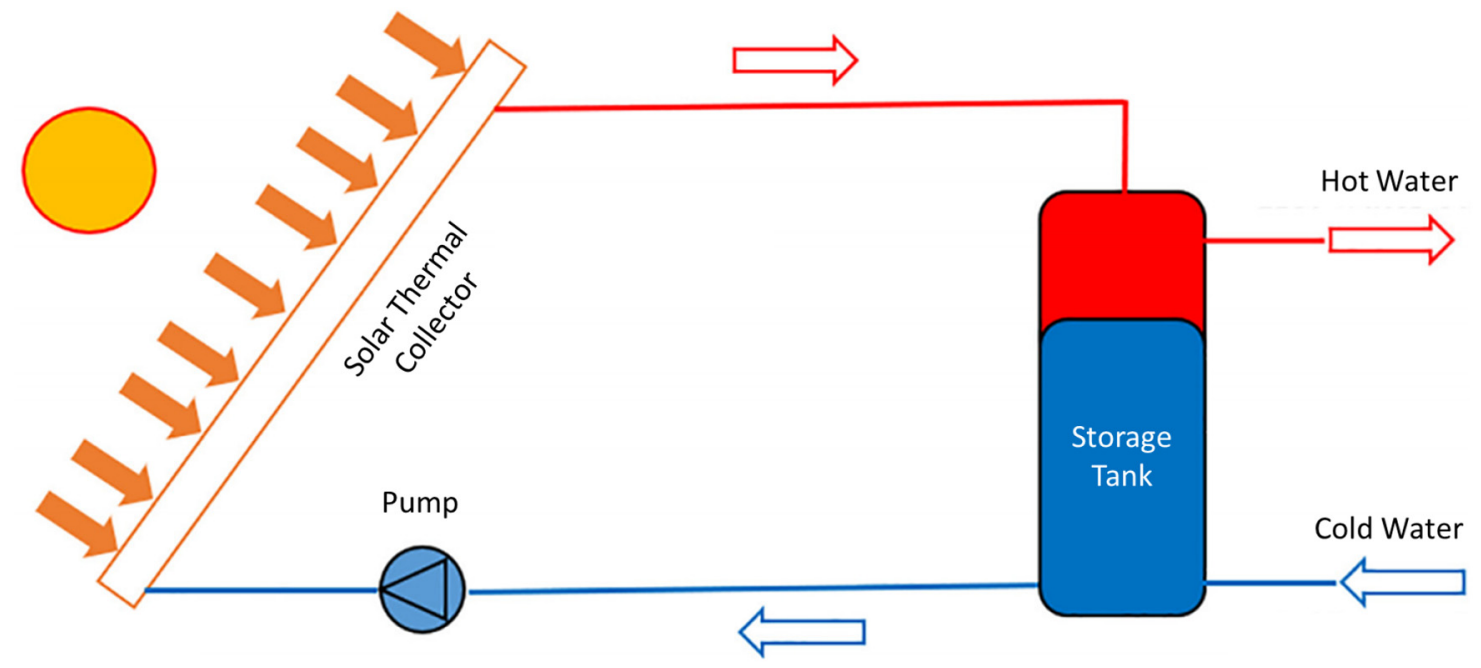

Fig. 1. Flowsheet of a solar thermal energy system including a solar collector and a water storage tank (schematics adapted from [6]).

$$
\begin{gathered}
P_{\text {pump }}=\frac{Q_{\text {pump }} \Delta p_{\text {pump }}}{\eta_{\text {pump }}} \\
q_{\text {supply }}=M_{\text {fuel,initial }} L H V \\
q_{\text {supply }}=M_{\text {fuel }} L H V+q_{\text {additional }} \\
q_{\text {additional }}=M_{\text {Water }} C_{p, \text { Water }}\left(T_{\text {Water }}-T_{\text {Water,initial }}\right) .
\end{gathered}
$$

Equations (1)-(3) that describe the component models described in Table $2: p_{\text {out }}$ and $p_{\text {in }}$ refer to the outlet and inlet pressure at a pipe, rspectively; $\Delta p$ refers to the pressure drop at the pipe; $p_{\text {final }}$ refers to the pressure at the bottom level of a water tank; $p_{0}$ refers to the pressure at the top of water tank; $\rho$ refers to the water density; $g$ refers to the acceleration of graivity; $y_{T}$ refers to the water level in the tank; $P_{\text {pump }}$ refers to the pump power; $Q_{\text {pump }}$ refers to the volumetric water flow rate; $\Delta p_{\text {pump }}$ refers to the pressure gain in the pump; $\eta_{\text {pump }}$ refers to the overall efficiency of the pump (which is the result of the multiplication of the hydraulic and mechanical efficiencies). In respect to equations (4)-(6) that describe the thermal processes, the total supplied heat in the boiler $\left(q_{\text {supply }}(\mathrm{kJ} / \mathrm{h})\right)$ may be calculated considering the fuel's lower heating value $(L H V)$, attending to equation (1) (only valid for the case in which there is only one heat source, which is fuel). For the case in which more than one heat source exists to supply thermal energy to the kiln, it is necessary to consider an additional heat parcel as described by equation (2), which corresponds to additional thermal energy contained in the inlet water stream $\left(q_{\text {additional }}(\mathrm{kJ} / \mathrm{h})\right)$, as described by equation $(3)$. It is to note the remaining nomenclature used in the set of equations (1) - (3): $M_{\text {fuel,initial }}-$ Baseline case fuel mass flow rate $(\mathrm{kg} / \mathrm{h}), M_{\text {fuel }}-$ Fuel mass flow rate $(\mathrm{kg} / \mathrm{h}), M_{c o m b, A i r}-$ Combustion air flow rate $(\mathrm{kg} / \mathrm{h}), C_{P, \text { Comb }, \text { Air }}-$ Air heat capacity $\left(\mathrm{kJ} /\left({ }^{\circ} \mathrm{C} . \mathrm{kg}\right)\right), M_{\text {Water }}-$ Water mass flow rate $(\mathrm{kg} / \mathrm{h})$, $C_{P, \text { Water }}-$ Water heat capacity $\left(\mathrm{kJ} /\left({ }^{\circ} \mathrm{C} . \mathrm{kg}\right)\right), T_{\text {Water }}-$ Water inlet temperature at the boiler $\left({ }^{\circ} \mathrm{C}\right)$, $T_{\text {Water,initial }}$ - Baseline case Water Inlet Temperature $\left({ }^{\circ} \mathrm{C}\right)$.

\subsection{Modelling of the solar thermal energy system}

The proposed solar thermal energy system (STES) was designed considering the layout presented in the Kumar et al. [6]. It corresponds to an industrial water circuit (IWC) constituted by two water flows, one which passes by a solar collector and the other that corresponds to the water that is supplied to the boilers. The STES (the whole installation excluding the boilers) is constituted by the solar collector, a centrifugal pump, a water storage tank and several pipelines. The system is presented in Figure 1.

The system model developed in Modelica environment, encompassing the water circuit and the two boilers is presented in Figure 2. The model has considered the components identified and described in the previous section.

A set of assumptions have been considered in the performance of the whole modelling:

- The air-to-fuel ratio in the boiler is constant, not varying according to different operational conditions;

- The ambient temperature has been considered at $25{ }^{\circ} \mathrm{C}$ and at the ambient pressure (1 bar).

\section{Results and discussion}

The main results obtained by the simulation of the assembled model are presented and analysed in this section. It is divided in two subsections, the first one related to the simulations results and model validation and a second one including a techno-economic assessment performed to evaluate the viability of its implementation. 


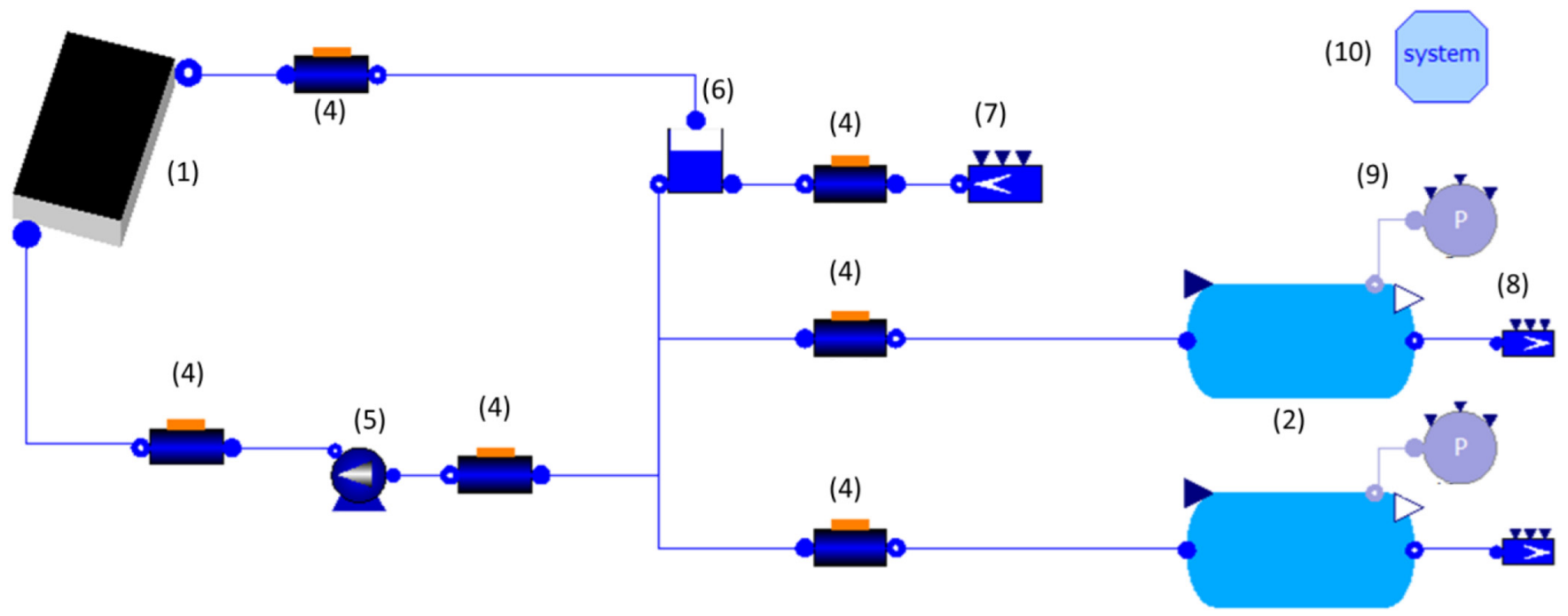

(3)

Fig. 2. Solar thermal energy system model built in OpenModelica: (1) Solar collector, (2) Boiler 1, (3) Boiler 2, (4) Pipes, (5) Pump, (6) Water storage tank, (7) Water Source, (8) Water Discharge, (9) Exhaust Gas Discharge, (10) System model.

Table 4. Simulation results and validation (boilers).

\begin{tabular}{|c|c|c|c|c|c|}
\hline \multicolumn{2}{|c|}{ Component } & \multirow[t]{2}{*}{ Variable } & \multicolumn{2}{|c|}{ Values } & \multirow[t]{2}{*}{ Deviation $(\%)$} \\
\hline & & & Simulation & Real & \\
\hline \multirow{4}{*}{ Boilers } & \multirow[b]{2}{*}{ Boiler 1} & Water Flow rate $(\mathrm{kg} / \mathrm{h})$ & 1277.38 & 1277.38 & 0.00 \\
\hline & & Water Outlet Temperature $\left({ }^{\circ} \mathrm{C}\right)$ & 94.99 & 95.00 & 0.01 \\
\hline & \multirow[b]{2}{*}{ Boiler 2} & Water Flow rate $(\mathrm{kg} / \mathrm{h})$ & 1180.32 & 1277.38 & 0.00 \\
\hline & & Water Outlet Temperature $\left({ }^{\circ} \mathrm{C}\right)$ & 94.99 & 95.00 & 0.01 \\
\hline
\end{tabular}

\subsection{Simulation results and model validation}

The assembled plant model was simulated using OpenModelica 1.14.1, an open source distribution of Modelica. The model conceptualized for both components and plants are developed in a basis of dynamic simulation, although the simulation performed for the purpose of model validation was realized in a steady state perspective the simulation values tend to stabilize at a certain point of the simulation attaining constant values.

By observing Table 4, the results for the validation of the two boiler models are consistent with real plant measured data. While for the circuit components it is not possible to perform such validation (as it consists in the conceptualised part of the model, not existing in real environment), Table 5 presents the outputs of the simulation which serve as the baseline of equipment sizing.

\subsection{Economic assessment}

Considering the simulation of the assembled model, a techno-economic assessment was performed in order to evaluate the viability of the project. This assessment has been performed by determining the overall economic savings taking into account an estimative for the investment cost and so getting the payback time,. The economic savings have been calculated considering the 2020 price rate for natural gas and electricity for industrial users $(9.64 € /$ GJ [22] and $0.1371 € / \mathrm{kWh}$ [23], respectively). The investment cost was roughly estimated considering the data present in the technical brief elaborated by IRENA and IEA-ETSAP [9]. Furthermore, a set of assumptions have been taken to perform this assessment:

- The economic evaluation overall considers a simple payback, not considering an inflation rate of the investment costs;

- Investments are considered to be intrinsic to the company, such as: consumables for repairs and substitution of equipment as the maintenance work.

The results for energy and economic savings are presented in Table 6 and the final determination of the payback time in Table 7 .

Regarding the energy balance, it is to note that appreciable economic savings are possibly to be obtained in the case that the economic savings produced by the fuel 
Table 5. Simulation results (circuit components).

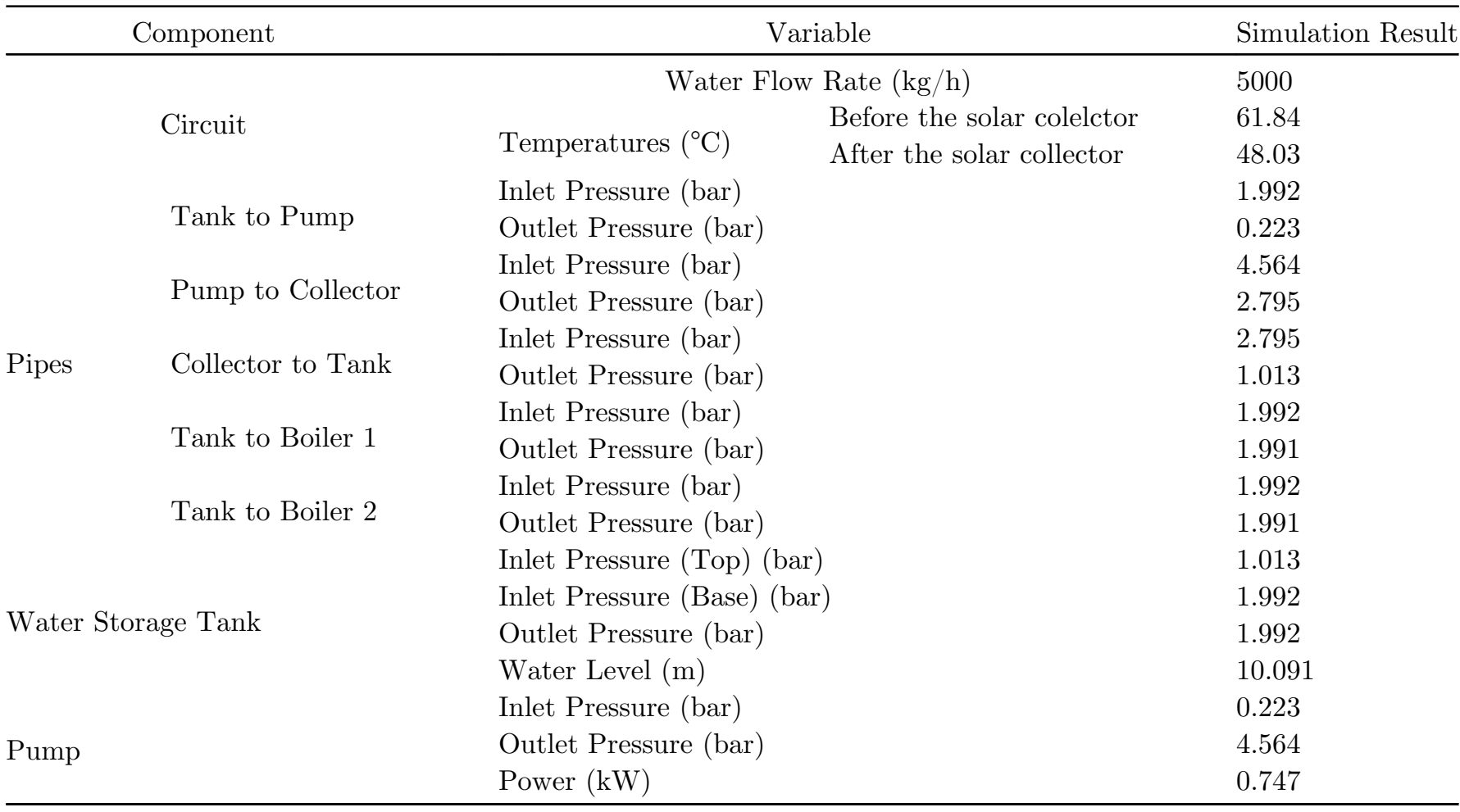

Table 6. Determination of energy and economic savings.

\begin{tabular}{|c|c|c|c|c|}
\hline \multicolumn{5}{|c|}{ Thermal Processes } \\
\hline & \multicolumn{2}{|c|}{$\begin{array}{l}\text { Energy Consumption } \\
(\mathrm{GJ} / \mathrm{h})\end{array}$} & \multirow[t]{2}{*}{$\begin{array}{l}\text { Energy Savings } \\
\text { (GJ/year) }\end{array}$} & \multirow[t]{2}{*}{$\begin{array}{l}\text { Boiler Economic } \\
\text { Savings }(€ / \text { year })\end{array}$} \\
\hline & Initial & Improved & & \\
\hline Boiler 1 & 3865.25 & 2486.25 & 1379.00 & 13293.56 \\
\hline \multirow[t]{2}{*}{ Boiler 2} & 3865.25 & 2546.03 & 1319.23 & 12717.37 \\
\hline & $\begin{array}{l}\text { Circuit } \\
\text { Energy } \\
\text { (MWh/ }\end{array}$ & $\begin{array}{l}\text { nents } \\
\text { nption }\end{array}$ & \multicolumn{2}{|c|}{$\begin{array}{l}\text { Additional Investment } \\
(€ / \text { year })\end{array}$} \\
\hline Pump & \multicolumn{2}{|c|}{$\begin{array}{l}5.85 \\
\text { Balance }\end{array}$} & \multicolumn{2}{|c|}{801.64} \\
\hline $\begin{array}{l}\text { Boiler Economic Savings } \\
(€ / \text { year })\end{array}$ & \multicolumn{2}{|c|}{$\begin{array}{l}\text { Additional Investment } \\
(1000 € / \text { year })\end{array}$} & \multicolumn{2}{|c|}{$\begin{array}{l}\text { Economic Savings } \\
(€ / \text { year })\end{array}$} \\
\hline
\end{tabular}

Table 7. Determination of payback time.

\begin{tabular}{lll}
\hline Economic Savings $(1000 € /$ year $)$ & Total Investment Cost $(€)$ & Payback Time (years) \\
\hline 25209.29 & 80000 & 3.17 \\
\hline
\end{tabular}


Table 8. Reduction of equivalent carbon dioxide emissions.

$\mathrm{CO}_{2_{\mathrm{eq}}}$ emissions parcels for natural gas and electricity

Reduction of $\mathrm{CO}_{2_{\mathrm{eq}}}$ emissions owing to natural gas savings (ton/year)

Additional $\mathrm{CO}_{2_{\mathrm{eq}}}$ emissions owing to electricity use (ton/year)

Total reduction of $\mathrm{CO}_{2}$ eq emissions

Total reduction of $\mathrm{CO}_{2_{\mathrm{eq}}}$ emissions (ton/year)

170.21

savings are more significant than the additional investment caused by electricity consumption namely by the circuit pump, which effectively is the case. The economic viability evaluation may be performed by comparing the estimated payback time (3.17 years) with reference values: comparing with typical energy efficiency improvement projects in the European industry (typical payback time of $2-3$ years [13]) the conceptualized project may be considered reasonably viable, while in comparison to solar water heating projects (considering an acceptable payback time of less than 20 years [24]) the economic viability is highly ensured.

\subsection{Environmental assessment}

The impact of he proposed system on the scope of sustainable development within a certain region (in this case Portugal), should considers the overall mitigation of environmental impacts. Such may be performed by determining the reduction of equivalent carbon dioxide emissions $\left(\mathrm{CO}_{2}\right)$ associated to the respective energy consumption- in this case associated to the use of natural gas and electric energy. The energy values may be converted to equivalent $\mathrm{CO}_{2}$ emissions $\left(\mathrm{CO}_{2 e q}\right)$ considering tabulated values for the respective emission factors for natural gas and electricity at the level of final energy use [25]. In Table 8 presentsthe reduction of $\mathrm{CO}_{2 \mathrm{eq}}$ emissions.

The $\mathrm{CO}_{2 \mathrm{eq}}$ emissions reduction may be assessed through its comparison with the mitigation associated to the implementation of energy saving measures in ceramic plants [26]. The 170.21 ton $\mathrm{CO}_{2 \mathrm{eq}} /$ year reduction associated to the implementation of the proposed measure (e.g. two hot water boilers) in terms of order of magnitude is comparable to the red-body stoneware tile kilns (to 555 ton $\mathrm{CO}_{2 e q}$ /year [26]). The firing stage in a ceramic plant, namely in ceramic kilns is associated to the highest energy use [8] and thus to the most significant GHG emissions within combustion processes. The mitigation potential associated to the energy savings in the studied hot water boilers is rather significant in the context of a single ceramic industry plant.

\section{Conclusion}

This paper presents an innovative approach for the improvement of energy efficiency in the industrial sector, namely through the use of renewable energy resources. This study focuses on the optimisation of thermal processes, which uses an innovative modelling and simulation tool developed in Modelica. A case-study inserted in a ceramic plant is analysed to improve the operation of two existing boilers. The approach includes a solar thermal energy systems (STES) for the use of solar energy as an additional heat source for the boilers. The conceptualised system has been modelled and simulated, enabling the validation of the models (it was obtained up to $0.01 \%$ deviation from measured data, which is rather succesfull), namely the energy consumption as well as the sizing of the water circuit encompassing the solar collector, in particular the parameters associated to the pump sizing (a pump power of $0.747 \mathrm{~kW}$ was obtained). A techno-economic has been performed considering the investment cost of the installation and the annual saving of $25209 € /$ year. A payback of 3.17 years has been determined. While the payback time is acceptable in the context of heat recovery and renewable energy projects, it is still high in comparison to other energy efficiency improvements projects for heat recovery in the ceramic industry. Nonetheless, such project may become economically viable by integrating other heat recovery projects which by themselves have low payback times. In respect to mitigation of environmental impacts, a reduction of 170.21 ton $\mathrm{CO}_{2 \mathrm{eq}} /$ year was estimated, which is a significant result compared to the mitigation potential assessed to the highest energy-consuming processes in a ceramic plant.

The validation and potential assessment of the presented modelling tool, serves as a conceptual basis for the ongoing overall research on thermal process optimisation. Future work includes the dynamic simulation of the conceptualised system and the performance of a life cycle assessment (LCA) of the project.

The publishing procedure and conference participation have received funding by the European Union's Horizon 2020 research and innovation programmes under grant agreement "No. 810764". This project has received funding from Portugal2020 03/SIAC/ 2016 under grant agreement "No. 26791".

\section{References}

1. Eurostat. Consumption of energy. Available online: https:// ec.europa.eu/eurostat/statistics-explained/index.php?ti tle=Archive:Consumption_of_energy (accessed on 30 March 2020)

2. R. Agathokleous, G. Bianchi, G. Panayiotou, L. Arestia, M. Argyrou, G.S. Georgiou, S.A. Tassou, H. Jouhara, S.A. Kalogirou, G.A. Florides, P. Christodoulides, Waste heat recovery in the EU industry and proposed new technologies, Energy Proc. 161, 489-496 (2019) 
3. K. Rajendran, J. Ling-Chin, A.P. Roskilly, Thermal energy efficiency in industrial processes, in Handbook of Clean Energy Systems (2015), p. 1-30

4. C. Reddy, S. Maidu, G.P. Rangaish, Waste heat recovery methods and technologies, Chem. Eng. 120, 28-38 (2013)

5. M.C. Fernandes, H.A. Matos, C.P. Nunes, J.C. Cabrita, I. Cabrita, P. Martins, C. Cardoso, P. Partidário, P. Gomes, Medidas Transversais de Eficiência Energética para a Indústria. 1st ed. Direção-Geral de Energia e Geologia: Lisbon, Portugal (2016) ISBN 978-972-8268-41-1

6. L. Kumar, M. Hasanuzzaman, N.A. Rahim, Global advancement of solar thermal energy technologies for industrial process heat and its future prospects: a review, Energ. Convers. Manag. 195, 885-908 (2019)

7. EUROPA, Available online: https://ec.europa.eu/clima/ policies/strategies/2030 en (accessed on 20 November 2020)

8. M.C. Oliveira, M. Iten, P.L. Cruz, H. Monteiro, Review on energy efficiency progresses, technologies and strategies in the ceramic sector focusing on waste heat recovery, Energies 13, 6096 (2020)

9. Solar Heat for Industrial Processes. Available online: https://www.irena.org/publications/2015/Jan/Solar-Heatfor-Industrial-Processes (accessed on 20 November 2020)

10. A.K. Sharma, C. Sharma, S.C. Mullick, T.C. Kandpal, Effect of incentives on the financial attractiveness of solar industrial process heating in India, Renew. Energy Environ. Sustain. 2, 33 (2017)

11. M. Romero, J. González-Aguilar, High-flux/high-temperature solar thermal conversion: technology development and advanced applications, Renew. Energy Environ. Sustain. 1, 26 (2016)

12. M.C. Oliveira, M. Iten, Modelling of industrial water circuits with a customised Modelica library, Appl. Therm. Eng. 169, $114840(2020)$

13. M. Iten, M. Oliveira, D. Costa, J. Michels, Water and energy efficiency improvement of steel wire manufacturing by circuit modelling and optimisation, Energies 12, 223 (2019)

14. M.C. Oliveira, M. Iten, H.A. Matos, J. Michels, Waterenergy nexus in typical industrial water circuits, Water 11, 699 (2019)

15. M.C. Oliveira, M. Iten, H.A. Matos, Assessment of energy efficiency improvement in ceramic industry through waste heat recovery modelling, Comput Aided Chem Eng 50, 1653 (2021)

16. Politecnico di Milano. ThermoPower Home Page. Available online: https://build.openmodelica.org/Documentation/ ThermoPower.html (accessed on 20 November 2020)

17. GitHub. WaterWatt Library. Available online: https:// github.com/miguelmcoliveira/WaterWatt-Library (accessed on 20 November 2020)

18. Soltermica Home Page. https://build.openmodelica.org/ Documentation/Soltermica.html (accessed on 20 November 2020)

19. SolarTherm Home Page. https://build.openmodelica.org/ Documentation/SolarTherm.html (accessed on 20 November 2020)

20. G. Hernandez-Albadejo, A. Urquia, Modelling of lowtemperature solar thermal systems with modelica, IFAC PapersOnLine 51, 783-788 (2018)

21. A. de la Calle, J. Hinkley, P. Scott, J. Pye, SolarTherm: a new modelica library and simulation platform for concentrating solar thermal power systems, SNE 3, 101-103 (2018)

22. PORDATA, Natural gas prices for households and industrial users (Euro). Available online: https://www.pordata.pt/en/ Europe/Natural + gas + prices + for + households + and + indus trial + users $+($ Euro)-1478 (accessed on 20 November 2020)

23. PORDATA, Electricity prices for households and industrial users (Euro/ECU). Available online: https://www.pordata. $\mathrm{pt} / \mathrm{en} /$ Europe/Electricity + prices + for + households + and + in dustrial + users $+($ Euro + ECU)-1477-804 (accessed on 20 November 2020)

24. Pure Renewables, Available online: https://purerenewables. co.uk/energy-solutions/solar-thermal/ (accessed on 20 November 2020)

25. Direç̧ão Regional da Economia de Lisboa Região de Turismo do Alto Minho (Costa Verde) (2008). Despacho n. 17313/ 2008 2008: 27912-3. Available online: https://www.pnaee. pt/wp-content/uploads/2020/10/Despacho-17313_2008.pdf (accessed on 26 July 2021)

26. A. Mezquita, E. Monfort, E. Vaquer, S. Ferrer, J.M. Pitarch, M.A. Arnal, Reduction of $\mathrm{CO}_{2}$-emissions in ceramic tiles manufacture by combining energy-saving measures, CFI Ceram Forum Int. 91, (2014) 